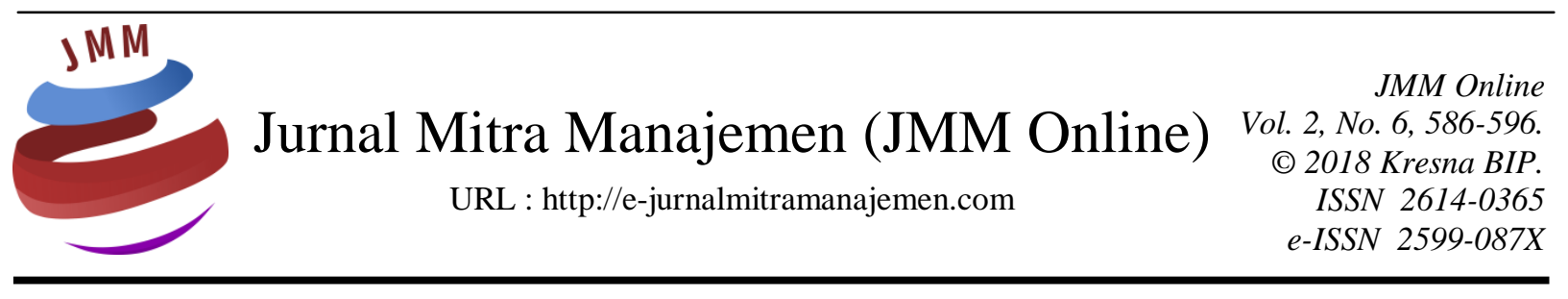

\title{
SISTEM INFORMASI INVENTORY BARANG KOPERASI KARYAWAN PERHUTANI CEPU BERBASIS WEB
}

\author{
Oktavenia Larasati \\ Universitas Muhammadiyah Surakarta
}

\section{INFORMASI ARTIKEL}

Dikirim : 02 Oktober 2018

Revisi pertama : 20 Oktober 2018

Diterima : 22 Oktober 2018

Tersedia online : 01 Desember 2018

Kata Kunci : Invetory, Sistem Informasi, Waterfall, Web

Email:oktavenia.ol@gmail.com

\section{ABSTRAK}

Koperasi Karyawan Perhutani Cepu adalah salah satu koperasi yang bergerak di bidang toserba (pembelian dan penjualan barang). Dalam bisnis tersebut pengelola menggunakan gudang sebagai tempat penyimpanan persediaan barang dagangan. Sistem persediaan barang (inventory) sangat penting guna membantu perusahaan dalam menjalankan proses bisnisnya. Sistem informasi mengenai persediaan barang di Koperasi Karyawan Perhutani Cерu masih menggunakan sistem manual, sehingga memungkinkan terjadinya kesalahan pada saat proses bisnis dan akan memakan waktu yang lama. Tujuan dari penelitian ini adalah untuk mengembangkan sistem informasi inventory barang Koperasi Karyawan Perhutani Cepu berbasis web. Metode pengembangan sistem yang digunakan adalah SDLC (System Development Life Cycle) yaitu model waterfall, terdiri dari tahap analisis, desain, pengkodean, pengujian dan pemeliharaan. Hasil pengujian black box menunjukan hasil yang valid, sedangkan untuk pengujian kuisioner mendapatkan hasil yang memuaskan dengan persentase rata-rata sebesar 92,8\%, yang menyatakan bahwa sistem ini dapat membantu Koperasi dalam proses pelaksanaannya. 


\section{PENDAHULUAN \\ Latar Belakang}

Pada era globalisasi ini, teknologi informasi adalah teknologi yang berkembang pesat dan membawa manfaat luar biasa bagi kehidupan manusia. Perkembangan teknologi membawa pengaruh besar dalam berbagai bidang, termasuk bidang bisnis. Sebuah perusahaan memerlukan sebuah teknologi yang dapat membantu perusahaan dalam menjalankan proses bisnisnya. Hal tersebut mengubah sistem yang masih manual menjadi terkomputerisasi (Sari \& Nuari, 2017).

Sebuah perusahaan harus menyusun data secara rapi dan dapat dikelola di dalam database sehingga akan menghasilkan informasi yang cepat dan tepat. Informasi tersebut akan digunakan sebagai data pendukung untuk mengelola persediaan barang. Pengelolaan data persediaan barang harus dilakukan dengan baik karena banyaknya jumlah dan jenis barang yang mungkin akan menimbulkan kesulitan pada proses pendataan (Prasetyo, 2017).

Persediaan barang adalah unsur paling penting yang harus dimiliki oleh suatu perusahaan dan salah satu syarat pokok yang wajib dipenuhi oleh suatu perusahaan dalam melakukan aktifitas perdagangan, karena dalam proses perdagangan yang diperdagangkan adalah persediaan barang itu sendiri (Manengkey, 2014).

Masalah persediaan barang meningkat seiring berkembangnya kemajuan teknologi yang mengakibatkan proses bisnis berjalan lebih cepat. Beberapa tahun terakhir beberapa perusahaan meningkatkan proses bisnisnya dengan cara bekerja sama dengan perusahaan atau organisasi lain untuk memenuhi kebutuhan pelanggan. Hal ini membuktikan jika proses bisnis berjalan sangat cepat dan perusahaan harus menyetarakannya (Ogbo \& Ukpere, 2014).

Menurut Puspitasari (2015), koperasi karyawan adalah sebuah instansi yang berada lingkungan sebuah perusahaan dan menyediakan berbagai produk untuk masyarakat dan karyawan perusahaan tersebut. Pengolahan dan penyimpanan data barang di Koperasi Karyawan Perhutani Cepu masih menggunakan sistem manual yaitu media kertas dan direkap ke dalam Microsoft Excel. Proses pengolahan data secara manual dapat mengakibatkan kesalahan dan ketidakakuratan dalam pengolahannya serta adanya resiko terjadinya kehilangan data akibat kesalahan manusia.

Berdasarkan uraian diatas, maka perlu untuk dirancang sebuah sistem informasi inventory berbasis web yang digunakan untuk mempermudah dalam menjalankan proses bisnisnya dengan meminimalkan dampak kesalahan dalam pendataan.

\section{Rumusan Masalah}

Berdasarkan latar belakang yang telah diuraikan, maka rumusan masalah yang dibahas ialah :

1. Pendataan barang pada gudang koperasi karyawan Perhutani Cepu masih diolah secara manual yaitu media kertas dan direkap ke dalam Microsoft Excel.

2. Bagaimana cara membuat sistem informasi inventory barang berbasis website sebagai media penyimpanan data barangyang efektif dan efisien di koperasi karyawan Perhutani Cepu. 


\section{Tujuan Penelitian}

Berdasarkan rumusanmasalah diatas, maka tujuan penelitian adalah untuk menyediakansistem informasi inventory barang yang diintegrasikan dengan website untuk dijadikan sebagai media penyimpanan data barang yang efektif dan efisien pada koperasi karyawan Perhutani Cepu.

\section{KAJIAN PUSTAKA}

\section{Sistem Informasi}

Sistem informasi adalah suatu sistem yang berada di dalam suatu organisasi yang mempertemukan kebutuhan pengelolaan transaksi, mendukung operasi, bersifat manajerial, kegiatan strategi dari suatu organisasi dan menyediakan laporan pada pihak tertentu untuk tujuan tertentu. (Hutahaean, 2015).

\section{Website}

Website adalah salah satu aplikasi yang berisi dokumen multimedia dan cara mengaksesnya menggunakan perangkat lunak yang disebut browser. Browser adalah aplikasi yang mampu menjalankan dokumen multimedia dengan caraditerjemahkan. Prosesnya dilakukan oleh komponen yang ada di dalam browseryang biasa disebut web engine (Arief, 2011).

\section{System Development Life Cycle (SDLC)}

SDLC adalah beberapa tahapan aktifitas yang berjalan dari awal sampai akhir dalam proses pengembangan sistem. Tahapan tersebut harus dicapai secara searah setelah menyelesaikan tahapan sebelumnya dan berurutan seperti tangga atau air terjun. Ada beberapa tahap yang berbeda pada metode ini, secara umum misalnya analisis kebutuhan, desain dan pengujian (Puspitasari, 2015).

\section{Inventory}

Inventory adalah semua barang atau aset yang dimiliki perusahaan baik untuk dijual atau digunakan untuk proses mengolah bahan mentah menjadi bahan jadi. Barang yang berwujud dapat disebut juga sebagai inventory, tergantung dari jenis usaha yang dijalankan perusahaannya (Rohayati, 2014).

\section{METODE PENELITIAN}

\section{Waktu dan Tempat Penelitian}

Pelaksanaan penelitian dilaksanakan selama 2 bulan yaitu pada bulan April 2018 hingga bulan Mei 2018. Penelitian dilaksanakan di "Koperasi Karyawan Perhutani Cepu" di Blora Jawa Tengah. Koperasi Karyawan Perhutani Cepu menyediakan berbagai kebutuhan rumah tangga, maka dari itu koperasi memiliki cukup banyak pelanggan.

\section{Perancangan Sistem}

Pengembangan sistem menggunakan metode SDLC (System Development Life Cycle) dengan model waterfall. SDLC terdiri dari tahap analisis, desain, pengkodean, pengujian dan pemeliharaan (Rosa \& Shalahuddin, 2013). 
Gambar 1. Metode Waterfall

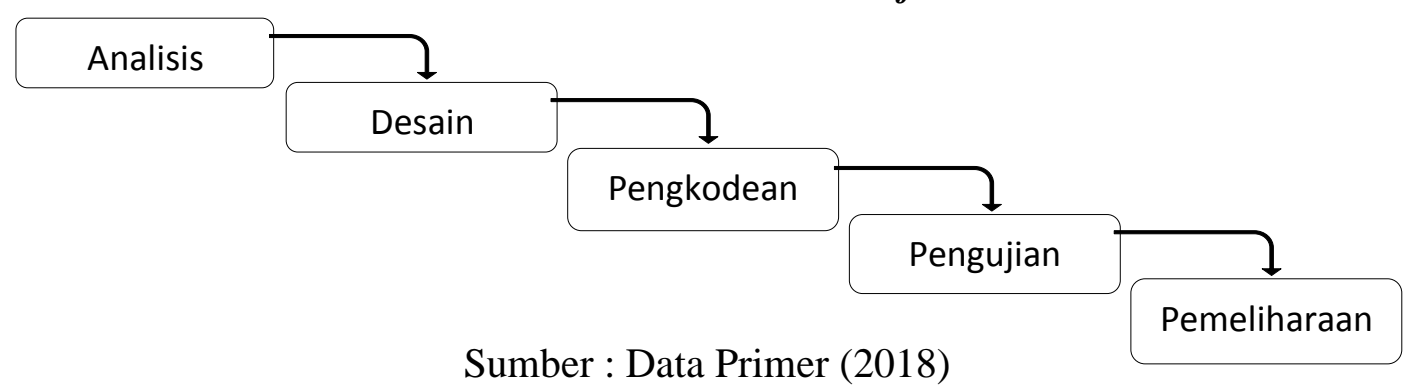

1. Analisis

Tahapan ini merupakan tahap menganalisa data-data yang didapatkan melalui observasi dan wawancara kepada pihak yang bersangkutan di Koperasi Karyawan Perhutani Cepu. Sistem yang akan dibangun harus menentukan siapa saja pelaku dan apa yang bisa dilakukan di dalam sistem.

2. Desain

Tahap penerapan rancangan sistem dari hasil observasi lapangan untuk menjadi suatu program yang hasilnya menjadi solusi permasalahan yang ditemui. Usecase digunakan untuk mendeskripsikan interaksi antara pengguna sistem dengan sistem yang akan dibuat. Berikut tampilan ditunjukan pada Gambar 2.

Gambar 2. Usacase Diagram

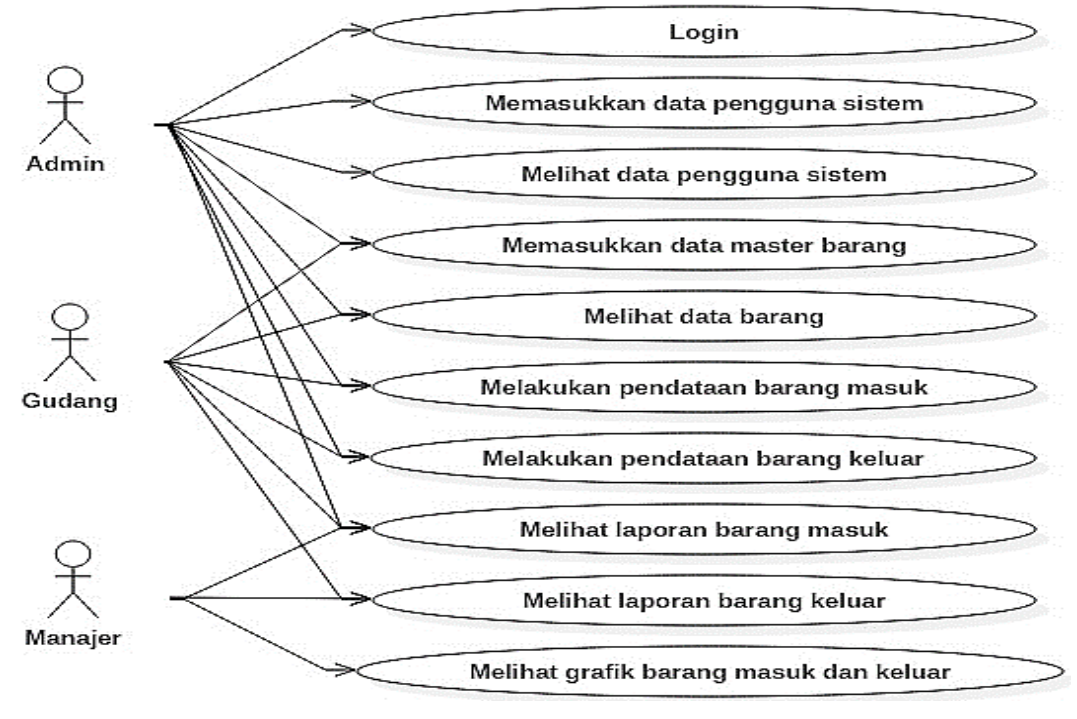

Sumber : Data Primer (2018)

Selanjutnya pembuatan desain halaman menggunakan aplikasi mock up sebagai media pembuatan desain user interface. Berikut adalah beberapa tampilan mockup Sistem Informasi Inventory Gudang Koperasi Karyawan Perhutani Cepu yang ditunjukan pada Gambar 3. dan Gambar 4. 


\section{Gambar 3. Halaman Beranda Admin}

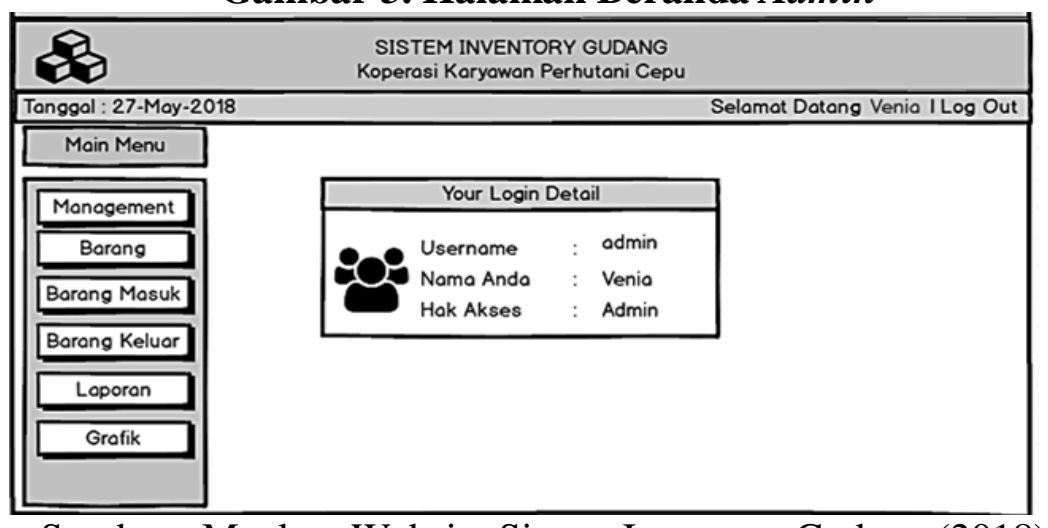

Sumber : Mockup Website Sistem Inventory Gudang (2018)

Gambar 4. Halaman Input Barang

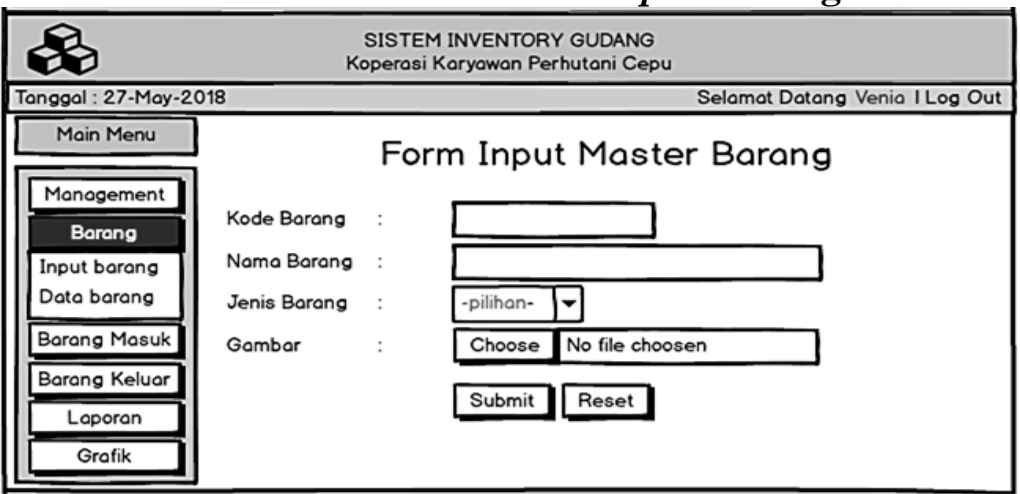

Sumber : Mockup Website Sistem Inventory Gudang (2018)

3. Pengkodean

Tahap ketiga adalah pengkodean. Tahap ini sama dengan tahap pembuatan program. Desain ditranslasikan ke dalam program perangkat lunak dengan menggunakan PHP sebagai kode pemrograman dan MySQL sebagai database. Hasil dari tahapan ini adalah program komputer yang sesuai dengan rancangan yang telah dibuat sebelumnya.

4. Pengujian

Pada proses ini dilakukan pengujian menggunakan black box dan kuisioner. Pengujian black box adalah uji coba pada sistem secara berulang untuk memastikan apakah sistem berjalan dengan baik atau tidak. Pengujian kuisioner adalah mengolah nilai dari beberapa poin pernyataan yang telah diisi untuk meminimalisir kesalahan dan memastikan hasil sesuai dengan keinginan pengguna sistem.

5. Pemeliharaan

Adanya kemungkinan terjadinya kerusakan pada sistem yang telah dikembangkan ketika sudah dikirim ke pemesan. Hal ini bisa terjadi karena adanya kesalahan yang tidak terdeteksi saat pengujian berlangsung. Pemeliharaan tidak perlu melakukan pembuatan sistem ulang, hanya melakukan perbaikan jika ditemukan kesalahan pada sistem. 


\section{HASIL PENELITIAN DAN PEMBAHASAN}

Pada tahap ini sistem telah selesai dikembangkan dengan adanya halaman beranda, menu dan fitur-fitur lain yang nantinya akan memudahkan pengguna dalam menjalankankannya.

1. Halaman Login

Halaman awal sistem ini merupakan halaman login. Untuk masuk ke dalam sistem diperlukan username dan password yang telah dibuat oleh admin. Berikut tampilan ditunjukan pada Gambar 5.

Gambar 5. Halaman Login

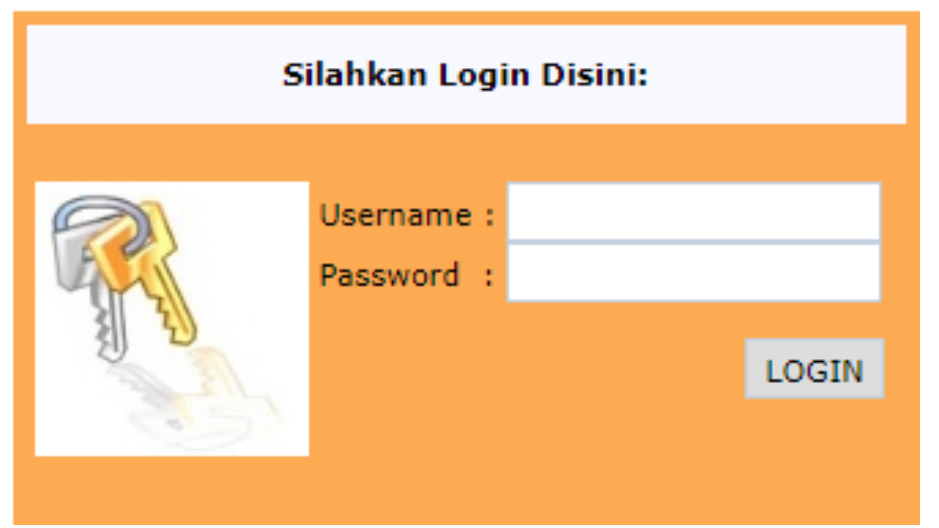

Sumber : Tampilan Website Sistem Inventory Gudang (2018)

\section{Beranda Admin}

Halaman selanjutnya adalah beranda, halaman ini memiliki menu yang berbeda tiap hak akses pengguna. Beberapa menu pada beranda memiliki submenu yang ditampilkan secara dropdown. Berikut adalah tampilan dari halaman beranda untuk hak akses admin ditunjukkan pada Gambar 6.

Gambar 6. Halaman Beranda Admin

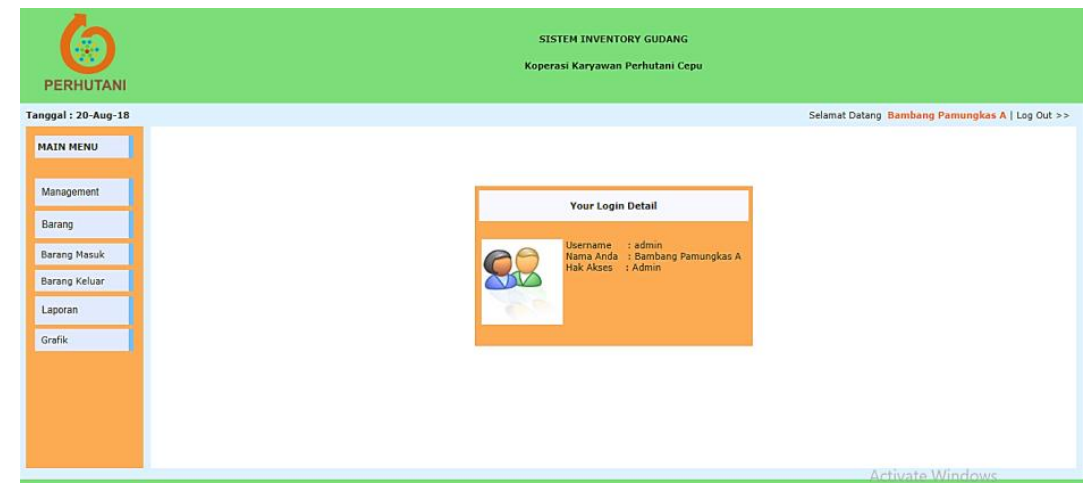

Sumber : Tampilan Website Sistem Inventory Gudang (2018)

\section{Halaman Input User}

Gambar 7 adalah halaman input useryang hanya terdapat pada hak akses admin dan berisi form untuk memasukkan data pengguna baru ke dalam sistem. Form input user terdiri dari username, namauser, password dan level hak akses. 


\section{Gambar 7. Halaman Input User}

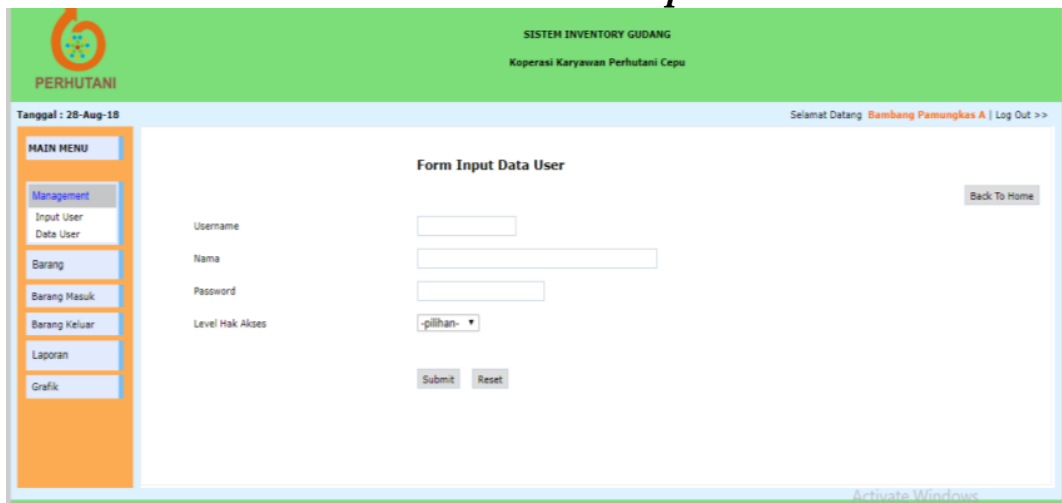

Sumber : Tampilan Website Sistem Inventory Gudang (2018)

\section{Halaman Input Barang Masuk}

Gambar 8 adalah halaman dari menu barang masuk untuk hak akses gudang. Pada halaman ini terdapat form untuk memasukkan data barang yang berisi id transaksi, tanggal, kode barang, nama barang, jenis barang, dan jumlah.

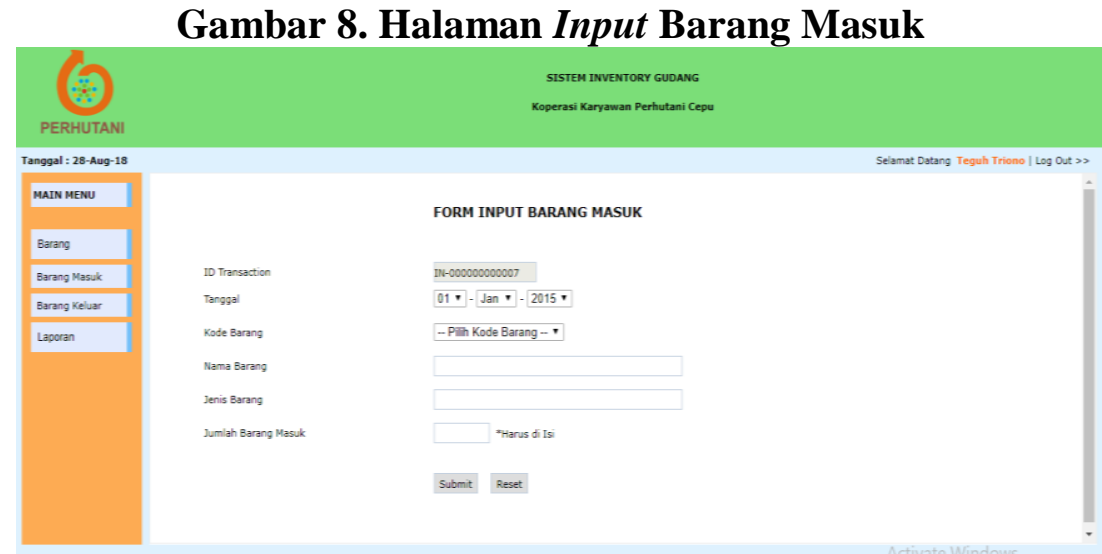

Sumber : Tampilan Website Sistem Inventory Gudang (2018)

\section{Pengujian Black Box}

Dalam pengembangan suatu sistem informasi tentu akan membutuhkan pengujian untuk menentukan tingkat keberhasilan sistem tersebut. Sistem ini dikembangkan melalui 2 pengujian yaitu black box dan kuisioner. Pengujian black box digunakan untuk menilai keakuratan fitur utama sistem. Adapun hasil dari pengujian black box ditampilkan dalam Tabel 1.

Tabel 1. Pengujian Black Box

\begin{tabular}{|l|c|l|l|c|}
\hline No. & Kriteria & \multicolumn{1}{|c|}{ Skenario } & \multicolumn{1}{|c|}{$\begin{array}{c}\text { Hasil yang } \\
\text { Diharapkan }\end{array}$} & $\begin{array}{c}\text { Hasil } \\
\text { Uji }\end{array}$ \\
\hline 1. & User login & $\begin{array}{l}\text { Jika } \text { username \& } \\
\text { password benar }\end{array}$ & $\begin{array}{l}\text { Berhasil masuk ke } \\
\text { dalam sistem sesuai } \\
\text { dengan hak akses }\end{array}$ & Valid \\
\hline
\end{tabular}


Lanjutan Tabel 1. Pengujian Black Box

\begin{tabular}{|c|c|c|c|c|}
\hline No. & Kriteria & Skenario & $\begin{array}{c}\text { Hasil yang } \\
\text { Diharapkan }\end{array}$ & $\underset{\text { Uji }}{\text { Hasil }}$ \\
\hline 2. & $\begin{array}{l}\text { User gagal } \\
\text { login }\end{array}$ & $\begin{array}{l}\text { Jika username \& } \\
\text { password salah }\end{array}$ & $\begin{array}{l}\text { Gagal masuk ke dalam } \\
\text { sistem dan kembali ke } \\
\text { halaman login }\end{array}$ & Valid \\
\hline 3. & $\begin{array}{l}\text { Input data } \\
\text { user }\end{array}$ & $\begin{array}{l}\text { Memasukkan data diri } \\
\text { user pada sistem }\end{array}$ & $\begin{array}{l}\text { Berhasil memasukkan } \\
\text { data user ke sistem }\end{array}$ & Valid \\
\hline 4. & Data user & $\begin{array}{l}\text { Masuk ke menu data } \\
\text { user }\end{array}$ & $\begin{array}{l}\text { Berhasil menampilkan } \\
\text { data } \text { user }\end{array}$ & Valid \\
\hline 5. & Input barang & $\begin{array}{l}\text { Memasukkan data } \\
\text { barang master }\end{array}$ & $\begin{array}{l}\text { Berhasil memasukkan } \\
\text { data barang master ke } \\
\text { sistem }\end{array}$ & Valid \\
\hline 6. & Data barang & $\begin{array}{l}\text { Melihat, mencetak, } \\
\text { mengubah dan } \\
\text { menghapus data barang }\end{array}$ & $\begin{array}{l}\text { Berhasil menampilkan, } \\
\text { mencetak, mengubah } \\
\text { dan menghapus data } \\
\text { barang pada sistem. }\end{array}$ & Valid \\
\hline 7. & $\begin{array}{l}\text { Barang } \\
\text { masuk }\end{array}$ & $\begin{array}{l}\text { Mengisi data jika ada } \\
\text { barang yang akan masuk } \\
\text { gudang }\end{array}$ & $\begin{array}{l}\text { Berhasil menyimpan } \\
\text { data barang masuk }\end{array}$ & Valid \\
\hline 8. & $\begin{array}{l}\text { Barang } \\
\text { keluar }\end{array}$ & $\begin{array}{l}\text { Mengisi data jika ada } \\
\text { barang yang akan keluar } \\
\text { gudang }\end{array}$ & $\begin{array}{l}\text { Berhasil menyimpan } \\
\text { data barang keluar }\end{array}$ & Valid \\
\hline 9. & $\begin{array}{l}\text { Laporan } \\
\text { barang masuk }\end{array}$ & $\begin{array}{l}\text { Melihat laporan } \\
\text { menggunakan filter } \\
\text { tanggal dan jenis barang } \\
\text { serta mencetak data }\end{array}$ & $\begin{array}{l}\text { Berhasil menampilkan } \\
\text { laporan sesuai tanggal } \\
\text { dan jenis barang yang } \\
\text { diinginkan serta dapat } \\
\text { menyimpan dengan } \\
\text { format pdf ataupun } \\
\text { mencetaknya }\end{array}$ & Valid \\
\hline 10. & $\begin{array}{l}\text { Laporan } \\
\text { barang keluar }\end{array}$ & $\begin{array}{l}\text { Melihat laporan } \\
\text { menggunakan filter } \\
\text { tanggal dan jenis barang } \\
\text { serta dapat mencetak } \\
\text { data }\end{array}$ & $\begin{array}{l}\text { Berhasil menampilkan } \\
\text { laporan sesuai tanggal } \\
\text { dan jenis barang yang } \\
\text { diinginkan serta dapat } \\
\text { menyimpan dengan } \\
\text { format pdf ataupun } \\
\text { mencetaknya } \\
\end{array}$ & Valid \\
\hline 11. & Grafik & $\begin{array}{l}\text { Admin/manajer melihat } \\
\text { grafik jumlah barang } \\
\text { masuk dan keluar } \\
\text { berdasarkan jenis barang }\end{array}$ & $\begin{array}{l}\text { Berhasil menampilkan } \\
\text { grafik sesuai } \\
\text { jumlahnya }\end{array}$ & Valid \\
\hline
\end{tabular}

Sumber : Hasil Penelitian, diolah (2018) 


\section{Pengujian Kuisioner}

Penilaian sistem dilakukan dengan melakukan pengisian kuisioner yang terdiri dari 5 buah pertanyaan yang kemudian diisi oleh pengguna sistem. Hasil dari kuisioner yang diisi oleh pengguna sistem akan diolah dan dihitung dengan menggunakan rumus skala likert. Skala likert adalah skala yang digunakan untuk mengukur hasil persetujuan pengguna terhadap sistem dan menyajikan pilihan skala yang disertai nilai pada setiap pernyataanpernyataan (Maryuliana, Subroto, \& Haviana, 2016). Adapun pernyataan pada kuisioner ditunjukan pada Tabel 2.

Tabel 2. Parameter Kuisioner

\begin{tabular}{|l|l|}
\hline No. & \multicolumn{1}{|c|}{ Kriteria } \\
\hline 1. & Apakah tampilan sistem sudah baik? \\
\hline 2. & Apakah sistem mampu mengurangi kesalah dalam pencatatan? \\
\hline 3. & Apakah sistem mudah digunakan? \\
\hline 4. & Apakah sistem mempermudah pendataan? \\
\hline 5. & Apakah fitur-fitur dalam sistem sudah baik dan lengkap? \\
\hline
\end{tabular}

Sumber : Hasil Penelitian, diolah (2018)

Kriteria penilaian digunakan untuk menentukan kriteria dari nilai persentasi suatu pernyataan ataupun rata-rata nilai persentasi dari semua pernyataan yang terdapat pada kuisioner. Adapun penentu kriteria ditunjukkan pada Tabel 3.

Tabel 3. Penentu Kriteria

\begin{tabular}{|l|l|l|l|}
\hline \multicolumn{1}{|c|}{ Kriteria } & $\begin{array}{c}\text { Nilai } \\
\text { Skala }\end{array}$ & $\begin{array}{c}\text { Total } \\
\text { Responden }\end{array}$ & \multicolumn{1}{c|}{ Persentase } \\
\hline Sangat Setuju (SS) & 5 & 5 & $81 \%$ sampai $100 \%$ \\
\hline Setuju (S) & 4 & 5 & $61 \%$ sampai $80 \%$ \\
\hline Normal (N) & 3 & 5 & $41 \%$ sampai $60 \%$ \\
\hline Tidak Setuju (TS) & 2 & 5 & $21 \%$ sampai $40 \%$ \\
\hline Sangat Tidak Setuju (STS) & 1 & 5 & $1 \%$ sampai 20\% \\
\hline
\end{tabular}

Sumber : Hasil Penelitian, diolah (2018)

Hasil dari penghitungan nilai persentase kuisioner seperti pada Tabel 4.

Tabel 4. Hasil Pengujian Kuisioner

\begin{tabular}{|c|c|c|c|c|c|c|c|}
\hline Kriteria & SS & $\mathbf{S}$ & $\mathbf{N}$ & TS & STS & $\begin{array}{l}\text { Total } \\
\text { Skor }\end{array}$ & Persentase \\
\hline $\begin{array}{l}\text { Apakah tampilan sistem sudah } \\
\text { baik? }\end{array}$ & 4 & 1 & 0 & 0 & 0 & 24 & $96 \%$ \\
\hline $\begin{array}{l}\text { Apakah sistem mampu mengurangi } \\
\text { kesalah dalam pencatatan? }\end{array}$ & 3 & 2 & 0 & 0 & 0 & 23 & $92 \%$ \\
\hline Apakah sistem mudah digunakan? & 5 & 0 & 0 & 0 & 0 & 25 & $100 \%$ \\
\hline $\begin{array}{l}\text { Apakah sistem mempermudah } \\
\text { pendataan? }\end{array}$ & 3 & 2 & 0 & 0 & 0 & 24 & $92 \%$ \\
\hline $\begin{array}{l}\text { Apakah fitur-fitur dalam sistem } \\
\text { sudah baik dan lengkap? }\end{array}$ & 2 & 2 & 1 & 0 & 0 & 23 & $84 \%$ \\
\hline ai persentase & & & & & & & $92,8 \%$ \\
\hline
\end{tabular}

Sumber : Hasil Penelitian, diolah (2018) 
Hasil dari pengujian yang telah dilaksanakan memperlihatkan bahwa 96\% responden menyatakan bahwa tampilan sistem sudah baik, 92\% responden menyatakan sistem telah mampu mengurangi kesalahan pencatatan, $100 \%$ responden menyatakan bahwa sistem mudah digunakan, 92\% responden menyatakan bahwa sistem telah mempermudah proses pendataan dan sebanyak $84 \%$ responden menyatakan fitur-fitur dalam sistem sudah baik dan lengkap. Hasil total jawaban dari responden untuk tiap pertanyaan pada kuisioner didapat dengan nilai rata-rata 92,8\%, sehingga dapat disimpulkan bahwa rata-rata responden sangat setuju dengan sistem yang telah dikembangkan.

\section{KESIMPULAN DAN SARAN Kesimpulan}

Sistem informasi inventory ini dikembangkan guna mempermudah karyawan Koperasi Karyawan Perhutani Cepu dalam melakukan pendataan stok barang yang ada di dalam gudang. Pengujian black box dilakukan dengan menguji fitur dan fungsi utama sistem. Pengujian tiap tahapyang dikerjakan memiliki hasil valid, dimana sistem tidak mengalami error saat dijalankan. Pengujian kuisioner dilakukan dengan membuat beberapa pertanyaan yang berhubungan dengan sistem untuk kemudian dinilai oleh 5 responden sebagai pengguna sistem. Hasil dari penilaian yang dikumpulkan dan diolah memperoleh hasil rata-rata $92,8 \%$ yang berarti pengguna sistem sangat setuju dengan sistem informasi inventory yang dikembangkan.

\section{Saran}

Sistem informasi inventory barang di Koperasi Karyawan Perhutani Cepu telah selesai dikembangkan dengan memperoleh hasil yang cukup memuaskan. Sistem informasi ini masih belum sempurna sehingga masih bisa dikembangkan untuk menjadi lebih baik lagi. Perbaikan pada tampilan serta penambahan fitur-fitur seperti penggunaan barcode untuk proses pendataan barang masuk agar lebih cepat.

\section{DAFTAR PUSTAKA}

Arief, M. R. 2011. Pemrograman Web Dinamis Menggunakan PHP dan MySQL. Yogyakarta: Andi.

Hutahaean, J. 2015. Konsep Sistem Informasi. Yogyakarta: Deepublish.

Manengkey, N. 2014. Analisis Sistem Pengendalian Intern Persediaan Barang Dagang dan Penerapan Akuntansi pada PT.Cahya Mitra Alkes. Jurnal EMBA, 2(3), 1321.

Maryuliana, Subroto, I. M., \& Haviana, S. F. 2016. Sistem Informasi Angket Pengukuran Skala Kebutuhan Materi Pembelajaran Tambahan Sebagai Pendukung Pengambilan Keputusan di Sekolah Menengah Atas Menggunakan Skala Likert. Jurnal Transistor Elektro dan Informatika, 1(2), 1-12.

Ogbo, A., \& Ukpere, W. 2014. The Impact of Effective Inventory Control Management on Organisational Performance : A Study of 7up Bottling Company Nile Mile Enugu, Nigeria. Mediterranean Journal of Social Sciences, 5(10).

Prasetyo, W. D. 2017. Sistem Informasi Inventaris Desa Berbasis Web. Diploma thesis, Universitas Muhammadiyah Surakarta. 
Puspitasari, D. 2015. Rancang Bangun Sistem Informasi Koperasi Simpan Pinjam Karyawan Berbasis Web. Jurnal Pilar Nusa Mandiri, 11(2).

Rohayati, M. 2014. Membangun Sistem Informasi Monitoring Data Inventory di Vio Hotel Indonesia, Jurnal Ilmiah Komputer dan Informatika (KOMPUTA), 1(1),18

Rosa, A. S., \& Shalahuddin, M. 2013. Rekayasa Perangkat Lunak Terstruktur dan Berorientasi Objek. Bandung: Informatika.

Sari, A. O., \& Nuari, E. 2017. Rancang Bangun Sistem Informasi Persediaan Barang Berbasis Web Dengan Metode Fast (Framework for the Applications). Jurnal PILAR Nusa Mandiri, 13(2), 261-266. 